\title{
Buddhist Translations Past, Present, and Future: With a Focus on Chinese and Tibetan Renderings
}

\author{
SAITŌ Akira*
}

Translation is of enormous importance in the field of humanities. This is true not only of reception of religious thought, philosophical texts, literary works, and other documents; it can be readily understood just by looking at translations into modern languages of many "classics." An accurate understanding of technical key terms is especially profoundly important in the cases of religious thought and philosophical texts. The first prerequisite is to have an accurate understanding of such technical terms in the contexts in which they appear in individual works, while considering their historical, cultural, and philosophical backgrounds.

Next the translator is faced with the necessity of choosing an equivalent in the target language that is sufficiently reliable and as masterful a translation as possible. When it is not possible to find existing vocabulary that is appropriate, the translator must use a transliteration (Buddha, bodhisattva, arhat, Sāmadhi, nirvāṇa) or create a Chinese neologism (yuanqi [縁起] for pratītya-samutpāda, foxing [仏性] for buddhadhātu, jingjin [精進] for vīrya, or zhongsheng [衆生] for sattva).

\section{Historical Translations of the Buddhist Scriptures}

As is commonly known, during the over 2,400 years of the history of Buddhism, Buddhist scriptures were translated directly from Indic languages into other languages (excluding examples of translations into modern languages) from the second century $\mathrm{AD}$ for Chinese and from the latter half of the eighth century for Tibetan, the latter being undertaken as a national enterprise. Later, translations were carried out in a broad sense from Chinese into Korean, Japanese, Vietnamese, and other languages; Mongolian translations were produced based on Tibetan translations. Further, there were trans-

* SAITŌ Akira 斎藤 明 is Professor emeritus of the University of Tokyo and director of Japanese Association of Indian and Buddhist Studies (JAIBS) 
lations and phonetic transcriptions from sacred Pāli texts into Sinhalese and Southeast Asian languages. Since the nineteenth century, there have continued to be translations from Sanskrit, Pāli, and other Indian languages into modern languages.

In keeping with the main topic of this paper, I will first briefly introduce the characteristics of Chinese and Tibetan translations and then provide some actual examples.

\section{A. Chinese Translations}

The following characteristics can be noted in Chinese translations. The first is that prior to Kumārajīva (350-409), that is, in the period of ancient translations, aside from a few exceptions, there were no translators proficient in both Indic and Chinese languages. Translations until the fourth century, during the Northern and Southern Dynasties (420-589), generally had not a few problems as Chinese-language texts, as well as with the level of their reliability as translated works.

Secondly, before the transmission of Buddhism, there had been a tradition in China of the Hundred Schools of Thought (諸子百家) centering on Confucians and Daoists (daojia 道家). Philosophical and cultural acculturation was sought, especially in terms of the various concepts of Laozi and Zhuangzi (the Daoists). Several examples come to mind, such as the Chinese translation of dao 道 (way) for bodhi (awakening); wuei 無為 for the nature of nirvāna (extinction); and the key concept of $w u$ 無 (nothingness) from daojia thought for śunna (emptiness). In terms of the last example, wu, the translation of kong (空 voidness) was eventually settled upon based on criticism of categorizing Buddhist concepts (geyi 格義). Thus, Dao An 道安 (312-385), who was at the vanguard of the criticism of categorizing Buddhist concepts, summarized the principles of translation of the Buddhist scriptures as wu shi ben san bu yi 五失本三不易 (literally, “the five errors that can't be avoided, three things that are not to be changed;" i.e., the five points that can't be avoided when translating the text, such as simplification of word order and repeated phrases, and three points to remember). On the other hand, Xuanzang 玄牀 (600/602-664) indicated that rather than translation, transliteration was appropriate for Buddhist technical terms, a concept he illustrated with five examples (wuzhong bufan; five “untranslatables" 五種不翻). I will touch on this subject again later.

Thirdly, and this is related to the first characteristic, because the translator into Chinese was assigned large volumes of material, there are pronounced differences in the quality of the translations. As a result, outstanding translators, such as Kumārajīva and Xuanzang, provided the prototypes for translations of terminology and texts. 


\section{B. Tibetan Translations}

In contrast, in Tibetan translations the following characteristics are observable. First, in terms of both script and acceptance of culture, there is a profound relationship between Tibet and India (and partially with China). Tibetan translations are strongly characterized by their considerably direct acceptance of Buddhist culture. From the end of the eighth century, the work of translation was carried out as a national enterprise systematically and in a concentrated manner based on cooperative effort between Indian scholars and Tibetan Lotsawa or translators of Buddhist texts.

The second characteristic is that there are many verbatim-like free translations. In contrast to Chinese translations, where all important technical terms use transliterations, such as those for Buddha, bodhisattva, or nirvāna, in Tibetan translations, free translations are the norm, as is exemplified by the term sangs rgyas (one who has awakened and opened up) for Buddha. Transliterations are rare. For Tibetans before the acceptance of Buddhism, all Buddhist terminology was new; there were generally no similar philosophical concepts to invite misunderstanding. For that reason, there was a background in Tibetan cultural history that made it comparatively easy to use free translation. What was referred to when making free translations were in many cases related treatises on interpretations of the sutras and annotations in India that offered conceptual prescriptions.

Thirdly, and this is related to the first characteristic, differences in the quality of translation are perceptible because of divergences in the ability of understanding and expression among Tibetan translators (or Indian scholars), but this was on a relatively small scale. Mahāvyutpatti (翻訳名義大集) and Madhyavyutpatti (同中集; 814) were compiled with the intention of unifying the methods of translation and translation terms, and could be said to be the background for fulfilling certain of these functions.

The following is an example that reflects the divergences in thinking behind the Chinese and Tibetan translations mentioned above. In terms of what's known as the most common name that disciples used for addressing Buddha, Bhagavat, the Chinese free translation includes Shizun (世尊 WorldHonored One) as well as the transliteration, Boqiefan (薄伽梵). Xuanzang in particular gives this as an example of the second case of five types of "untranslatables;" that is, a word that cannot be rendered in free translation owing to its having multiple meanings.

Dharma master Xuanzang of Tang China clarified the five types that are not to be rendered in free translation. First, terms that are secret; the dhärañi (陀羅尼) incantation is one of these. Second, terms that have many [meanings] are not to be expressed in free translation; Bhagavat 
(薄伽梵 Blessed One) has six meanings so it is included in this category. Third, things that do not exist in China are not to be translated, including words such as the jambu tree (閻浮樹). Fourth, terms that follow old [traditional transliterations] are not to be translated, such as anuttara [samyaksam] bodhi [the supreme and perfect enlightenment], 阿誫 [多羅 三貌三] 菩提). Actually, this can be conveyed in free translation [such as the wushang zhengdeng jue 無上正等覚] (The Supreme Way of Right Seeing), but because of the Sanskrit transliteration since [Käśyapa] Mātanga [first introduced Buddhism to China in the Later Han period], transliteration has been used. Fifth, words that are not rendered as free translations in order to create virtue; [the transliteration] bore (般若) is august and serious whereas zhihui (智慧) is casual and shallow. This is not translated in order to engender a sense of respect in people. (Note 1)

Thus, Xuanzang considered free translation to be appropriate for all five representative concrete examples that he gave. In contrast, in Tibetan, except for the first example of dhärañ $\bar{l}$ and the third of the Indic proper noun, jambul, it was common for all to be rendered as free translations.

Next I will examine the examples of Bhagavat from the sGra-sbyor bam-po gnyis-pa or Madhyavyutpatti (Middle Etymological-Glossary), which indicates the basis for translating over 400 important technical Buddhist terms. The Tibetan translation for the same word is bcom ldan 'das; the same text explains the basis for the translation below.

Concerning bhagavat $=$ bcom ldan 'das, for one thing, one is called Bhagvān because he conquers the four demons (Māra) (bhagnamāracatuştayatvād). That is, because he conquers (bcom pa) the four demons [i.e., the demons of aggregates, defilements, death, and the heavenly Evil one], he is called "one who conquers" (bcom pa). Another [interpretation] is that bhaga is the name for the "six kinds of virtues". These refer to appearance, fame, omnipotence, auspiciousness, wisdom, and endeavor, which all have the common characteristic of being "virtues." The reason that -vat appears is that the person has virtue (bhago 'syāstīti) and is therefore Bhagavān (one who has virtues), so is explained as ldan $p a$ (one who has...).... Since he has "far more" [virtue] than Bhagavān, the god of the world, 'das has been appended and he was called in particular bcom ldan 'das, "one who conquers, has [virtues], and transcends [the god of the world]."... The god [of the world], Bhagavān, is [simply] called legs ldan (one who possesses good). (Note 2)

As can be seen above, the Tibetan translation uses the fairly standard 
translation, bcom ldan 'das, which at first glance is difficult to understand in that it means "one who conquers, possesses, and transcends." As can be surmised from a similar explanation in Arthaviniścaya-sūtra and its Commentary written by Bhikșu Vīryaśrīdatta (a scholar from the latter part of the eighth century at Nālandā, India), as referenced in Note 2, this is a result of Tibetan respect for the tradition of Abhidharma of the early Sarvāstivāda school of Buddhism. As in the case of the previously mentioned translation of sangs rgyas (one who has awakened and opened up) for the word, "Buddha," even if this was a type of popular etymological interpretation, it respects the traditional semantic understanding and is the result of an attempt to reflect the free translation as faithfully as possible.

\section{Modern Translations of the Buddhist Scriptures and Buddhist Terminology}

Here I will be considering once more the merits and demerits of the Chinese translations of Buddhist terminology that comprise the foundation of Japanese Buddhism based on the divergent characteristics of the Chinese and Tibetan translations, which I discussed above.

\section{A. Impediments to a Philosophical Understanding of Buddhism}

In Japan, Buddhism has played an important role as a substratum in cultural traditions. It would be impossible to talk about Japanese cultural traditions, including various forms of Buddhist faith, annual events, funeral rites, temple construction, landscape design, many Buddhist statues and paintings, and traditional arts such as iroha poems and the fifty sounds of the kana alphabet, without talking about Buddhism.

Then what about the philosophical understanding of Buddhism? Unfortunately, it must be said that there are very few opportunities for Japanese to read the Buddhist scriptures directly or deepen their understanding of Buddhist thought. This is in spite of the fact that Buddhist statues have always been beloved, many Japanese have deep feelings about the distant sounds of the temple bell on New Year's Eve, make their first visit of the year to a temple on New Year's day, or are disposed, even now, to follow Buddhist funeral rites for their relatives, albeit the tradition is in decline.

There are several reasons for this. From ancient times, 1) a profound significance was assigned to reciting the Buddhist scriptures, and it was accepted that treatises and annotations on the scriptures were studied by learned priests. 2) The study of Buddhist texts (sutras, treatises) meant classical texts related to founders of sects, and religious doctrine was studied as transcriptions of classical Chinese into Japanese. 3) Ordinary people have to come into contact with the Buddhist scriptures through Buddhist memorial 
rites and bereavement meals, Buddhist tales and essays; it can be said that traditionally the common people have had little opportunity for direct contact with the Buddhist scriptures. Further, 4) in the modern era, Sanskrit and Pāli have begun to be studied and research on original texts has progressed, but for better or worse, in many cases the tradition of prioritizing the reading of Chinese texts as Japanese and of Chinese translations has been retained.

\section{B. Merits and Demerits of Confucian Translations: Examples of Problems concerning Interpretation of Buddhist Terminology}

What are the merits and demerits of adhering to the Buddhist terminology translated from Chinese to deepen philosophical understanding of Buddhism?

As is well-known, a vast number of specialized terms appear in the texts and treatises of Buddhism. Among them, most translations into various languages are based on middle Indo-Aryan languages, including Sanskrit and Pāli. In particular, translations into Chinese terminology, such as 四聖諦 (Ch: sishengdi / J: shishōtai [catvāri ārya-satyāni]), 五蓝 (除) (Ch: wuyun(yin) / J: go'un (on) [pañca-skandha]), 無我 (Ch: wuwo / J: muga [anātman]), or 縁起 (Ch: yuanqi / J:engi [pratityasamutpāda]), became widely established in the Buddhist world of East Asia and are still in use today. Further, while the concepts derive originally from India, this specialized vocabulary contains not a few cases of technical terms formulated in the process of the development of Chinese Buddhism (e.g., 理事無礙 Ch: lishi wu ai / J: rijimuge [principle of emptiness coexisting with concrete phenomena based on commentaries by the monk Chengguan 澄観; 738-839], 十界互具 Ch: shijie xiangju / J: jikkai gogu [both Buddha and hell are in one's heart], and 草木成仏 C: caomu chengfo J: sōmoku jōbutsu [even grasses and trees can attain Buddhahood]).

In any case, it could be said that from the beginning, Gautama Buddha reflected the intellect and sensibilities honed by transmitters and various scholars who enumerated both Buddhist sutras and laws. In addition, while translators of the Buddhist sutras and laws worked within the context of their own philosophical and historical backgrounds and sect traditions, their struggles to create lexica appropriate for expressing each thought should not be overlooked. There are many brilliant, concise translations among these traditional terms, including yuanqi / engi 縁起 [dependent origination], wuwo / muga 無我 [non-self], (feiwo / higa非我 [not oneself]), and zhongdao / chüdō 中道 [the middle path], which long ago became conventional translations in Japanese.

Nevertheless, it is not easy to understand precisely some of the traditional single character Chinese translations, especially for terms such as 法 $(\mathrm{fa} / \mathrm{h} \bar{o})$ [dharma], 蓝 ( yun / un) [skandha: aggregate], 処 (chu/ sho) [āyatana: field], 界 (jie / kai) [dhātu: cosmos], 色 (si / shiki) [rūpa: appearance of material 
objects], 受 (shou / ju) [vedanā: sensation], 想 (xiang / sō) [samjñā: representation], and others, whether they are heard or one knows the Chinese characters. There should be important illustrations and their contexts for the understanding of the translated lexica, but there are not a few cases when the translations cause misunderstandings.

Next I will discuss the term 集 (Ch: $j i / \mathrm{J}: j \bar{u})$, which literally means "collection" and is one of the Four Noble Truths (catvāri āryasatyāni): 苦 (Ch: ku / J: ku: pain), 集 (collection), 滅 (Ch: mie /J: metsu: suppression [of pain]), and道(Ch: dao / J: dō: path).

The Sanskrit words for the Four Noble Truths are duhkha (suffering), samudaya (arising / cause), nirodha (suppression), and mārga (path) respectively. Samudaya refers to the arising of suffering or the cause of that arising. Accordingly, when these terms are translated into modern languages (Japanese, English), the corresponding terms of "arising" or "cause" are used. The other three Noble Truths mean "suffering," "suppression, control," and "way, path." Compared with the word in the original Sanskrit, the Chinese translation 滅 (mie: extermination) has a rather strongly negative nuance, but other than that, there are no large problems with the traditional Chinese translations.

The important point I will pursue next will be the definitions behind the modern translations and major illustrations. I will very briefly discuss this issue below. It is probable that the above-mentioned modern translations of "arising" or "cause" for samudaya are based on the following Buddhist texts and annotations passed down in Pāli or Sanskrit:

evam etassa kevalassa dukkhakkhandhassa samudayo hotil

(SN II, p.17.26-27, 29-30)

In this way there is an arising (samudaya) of a congregate of all suffering.

evam asya kevalasya mahato duhkhaskandhasya samudayo bhavatītil

(AKBh, pp.135.5-6, 139.12, 140.21)

In this way, there is an arising of a congregate of all of this massive suffering.

samudety asmād duhkham iti samudayahl

(AKBh, p.5.16)

Because suffering arises from this, it is the cause.

samudety asmād duhkham iti samudaya iti. hetu-bhütāh skandhāh samudayah. phalabhūtāh skandhā duḥkham iti varnayanti.

(AKVy, p.23.4-6) 
They say that "because suffering arises from this, it is the cause," which means that the causal [five] aggregates constitute samudaya (cause), and that the resulting aggregates are dukkha (suffering).

Why is it that Kumārajīva and Paramārtha, as well as Xuanzang, all assigned the translation $j i$ 集 to samudaya, which means the "arising" or the "cause" of suffering (there were also the translations for the word samudaya: 集生 [jisheng] and 和合生 [hehesheng])? One plausible reason was that when the Four Noble Truths of duḥkha, samudaya, nirodha, and mārga were represented with one translation term, the prefix sam- was often translated as 集 $(j i)$, which was mechanically used here as well. That is, the sam- $(j i)$ of samudaya (集起 jiqi; 集生 jisheng) had been used from ancient times, and that tradition was preserved.

\section{The Project for Constructing Bauddhakośa: A Treasury of Modern Standard Translations of Buddhist Terms and Definitive Illustrations}

As I mentioned in the introduction, in order to deepen understanding of Buddhist thought, what is most essential is an accurate, corresponding contextual understanding of important terms. Scholars with this mindset have always individually attempted translations into modern languages. Today, it is becoming more necessary to bear in mind the results of this valuable work and to offer modern translations based on the standards or the "foundation" of important Buddhist terminology and that are built on an accurate understanding of traditional Chinese translations.

Lastly, here I would like to end my essay by introducing our project, "Project for Constructing Bauddhakośa: A Tresury of Modern Standard Translations of Buddhist Terms and Definitive Illustrations," which is funded by Grant-in-Aid for Scientific Research (A). Now there are many academic workshops related to the "five groups of the one-hundred modes" in the Yogachara school of Buddhism. Below is one example of research on the seventy-five dharmas of the Abhidharmakośa-bhāṣya of the Sarvāstivāda school of Buddhism that has already been made public. Traditionally, manaskāra (translated into Chinese as zuoyi 作意 [mental engagement] by Xuanzang), was one of the ten universal mental functions (mahābhūmika). In accordance with the definitive illustration given in the Abhidharmakośabhāsya verses, at the same time that the modern translations contained therein suggest "devotion" or to "give attention to," the work also provides the original text that forms the basis of the translation, translated passages, and related traditional translations, annotated texts, and examples of translations into Western languages. (For details, see the following website: http://www. 
1.u-tokyo.ac.jp/ b_kosha/start_index.html).

\section{Example:}

manaskāra

Chinese translation: 作意 zuoyi (“mental engagement;” Xuanzang); 思惟 siwei ("thought;" Paramartha);

Tibetan translation: yid la byed pa (= Mvy no.1926)

Standard translation: 傾注 (devotion), 心を向けること (to direct one's attention to)

[E.] attention

\section{Definitive illustrations:}

Japanese translation: 傾注とは心を〔特定の対象に向けて〕はたらかせることで ある。

Original text: manaskāraś cetasa ābhogah/ (Abhidharmakośabhāsya of Vasubandhu ed. by Pradhan, 1967, 54,22, Chap.II v.24b)

Xuanzang's translation: 作意謂能令心警覺。(『阿毘達磨俱舍論』大正29巻19a21) (See Puguang's interpretation [普光釈を見る])

Paramartha's translation: 思惟謂心迴向。(『阿毘達磨俱舍釋論』大正29巻178b15)

Tibetan translation: yid la byed pa ni sems kyi 'jug pa'o (Chos mngon pa'i mdzod kyi bshad pa 北京版115巻72a8)

Annotated texts: Abhidharmakośavyākhyā: (ed.by U.Wogihara, 1932-36, 127) manaskāraś cetasa ābhoga iti. ālambane cetasa āvarjanam. avadhāraṇam ity-arthaḥ. manasaḥ kāro manaskāraḥ. mano vā karoti āvarjayatīti manaskārah.

『阿毘達磨順正理論】: (玄牀訳, 大正 29巻, 384b8-9)

引心心所。令於所緣有所警覺。説名作意。此即世間説為留意。

Examples of Western translations: Pruden [1988: 190]: the act of attention;

La Vallée Poussin [1923: 154]: acte d'attention (文例略)

Related sources:

Other Abhidharma texts (その他のアビダルマ文献)

Vijñānavāda texts (瑜伽行派の文献)

\section{Conclusion}

As can be seen above, a philosophical understanding of Buddhism must first be based on constant consideration of the background of historical thought in which the meaning of each term belonged in context and the selection, as much as possible, of appropriate, simple translations based on various shades of meaning of translation, linguistic impressions, and actual examples. As can be seen in the sentence below, such principles are the same as those used in Tibet when many Buddhist texts were translated as part of a national endeavor at the beginning of the ninth century. 
"The method of translating the true teachings of Buddha is to make the Tibetan words simple without changing the original meaning."

dam pa'i chos bsgyur ba'i lugs ni don dang yang mi 'gal la bod skad la yang gar bde bar gyis shig/ ("Prefix, Sgra sbyor bam po gnyis pa” 二巻 本訳語釈, Ishikawa Mie, Studia Tibetica, no.28. Materials for TibetanMongolian Dictionaries, vol.3 [1993] p.2)

\section{Notes}

1 唐玄牀法師明五種不翻。一秘密故不翻。陀羅尼是。二多含故不翻。如薄伽梵含六義 故。三此無故不翻。如閻浮樹。四順古故不翻。如阿蓐菩提。實可翻之。但摩騰已存梵 音故。五生善故不翻。如般若尊重智慧軽浅。令人生敬、是故不翻。」(『翻訳名義集』南 宋・法雲編、大正 No.2131, vol.54, 1057c7-12)

2 bhagavat = bcom ldan 'das: gcig tu na/ bhagnamāracatuş̧ayatvād bhagavān* zhes bya ste/ bdud bzhi bcom pas na bcom pa la bya/ yang rnam pa gcig tu na bhaga ni legs pa rnam pa drug gi ming ste/ gzugs dang/ grags pa dang/ dbang phyug dang/ dpal dang/ shes rab dang/ brtson ps ste/ 'di drug gi spyi la bya/ vān zhes 'byung ba ni bhago 'syāstīti bhagavān zhes ldan par bshad de/.../'jig rten pa'i lha bhagavān las khyad par du 'das shes bla thabs su bsnan te/ bcom ldan 'das shes btags/...'jig rten pa'i bhagavān ni legs ldan zhes gdags/ (sGra sbyor bam po gnyis pa, Ishikawa [1990] pp.6-7)

*Cf. Arthaviniścayasūtranibandhana, Samtani ed., pp.76.4-77.3: bhagavān iti māracatuşţayạ̣ devaputrakleśaskandhamṛtyulakṣaṇaṃ bhagnavān iti kṛtvā nairuktena nyāyena bhagavān/ aiśvaryādiguṇayogād vā, yathoktam aiśvaryasya samagrasya rūpasya yaśasạ̣ śriyaḥ/ jñānasyātha prayatnasya şaṇnām bhaga iti śrutị̣// iti/ 